\title{
Trends in International Education: New Imperatives in Academic Librarianship
}

\author{
Martha L. Brogan
}

The author describes new directions in international education during the past decade and links them to new imperatives in academic librarianship. Five major areas of development are considered: foreign language instruction, study abroad, internationalizing the curriculum, foreign students and scholars, and technical assistance and international development. The author recommends six ways in which ACRL might strengthen its role as an advocate of international education.

This article was written in connection with the work of ACRL's task force on international relations.

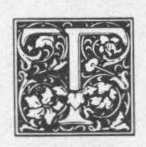

en years ago the President's Commission on Foreign Language and International Study issued a report entitled Strength through Wisdom: A Critique of U.S. Capability that stressed the need to integrate an international dimension into the college curriculum. Among other widely publicized findings, it revealed that less than 10 percent of Americans could read and speak a foreign language effectively, that few were highly skilled and few were competent in a language other than Spanish, French, or German. ${ }^{1}$ The dearth of international knowledge among college students, including basic information about geography, politics, and economics, was further documented in the 1981 report, College Student's Knowledge and Beliefs: A Survey of Global Understanding. ${ }^{2}$ Numerous other studies during the 1980 s continued to examine the role of foreign language instruction, study abroad, international curriculum, foreign students, and overseas technical assistance in higher education. ${ }^{3}$

In academic institutions the argument for increasing the international competence of students is twofold, stemming from educational and economic imperatives. Developing the skills necessary to succeed in a multicultural, interdependent world is both educationally responsible and the only means of survivaleconomic and otherwise-in the twenty-first century. Increasingly, the United States' economic pre-eminence is being replaced by international economic competition in a global marketplace. Educators now realize that national policies alone cannot resolve the global challenges of environment, sustainable agricultural systems, improved health systems and population planning, and urban development. The United States is only one partner in a global network. During the 1980s institutions of higher education recognized their role in educating internationally competent citizens as well as developing a cadre of highly skilled future leaders who might succeed in the global arena.

We are now beginning to witness concrete outcomes, and a coalescing of opinion about the importance of internationalizing higher education. At the national level, the Coalition for Advancement of Foreign Language and International Stud-

Martha L. Brogan is Social Sciences Bibliographer, Sterling Memorial Library, Yale University, New Haven, CT 06520. 
ies (CAFLIS), founded in 1987, serves as a focal point for these discussions. CAFLIS has promoted the proposal to create $\mathrm{a} \mathrm{Na}$ tional Endowment for Foreign Language and International Studies, which would work with public and private colleges and universities, associations, and school systems to strengthen international competence. ${ }^{4}$

At the state level, the National Governors' Association released its study of international education, America in Transition: The International Frontier, in March $1989 .^{5}$ The report discusses the effects of globalization on state economies and work forces and outlines a "state action agenda" for elementary and secondary schools, higher education, and business. The governors' recommendations for higher education include strengthening the study of foreign languages, increasing participation in study abroad, and integrating an international dimension in all majors at the college level. Many states already have introduced programs to improve the international competence of their citizens, and this new report undoubtedly will result in even broader participation. ${ }^{6}$

A special Higher Education Panel (HEP) survey of colleges and universities covering the period from 1982 it 1987, supported by the American Council on Education (ACE) was issued in September $1988{ }^{7}$ It reported increases in hiring new faculty with international expertise, international course offerings, libraries' international collections, opportunities for study abroad, and opportunities for faculty travel overseas.

To summarize, the current period in international education is characterized by consolidation and reconfiguration. ${ }^{8}$ Since the end of the Second World War there has been unprecedented growth on almost all campuses in teaching about other parts of the world and in international exchanges of student and faculty. Therefore, the main task ahead is not to add more courses, but to sharpen the definitions of international education, and to build into a cohesive whole the existing, usually disparate component parts. Institutions see the need to integrate and direct growth from widely dispersed, largely student demand-driven initiatives into rational institutional plans. To this end, many are appointing high-level administrators specifically assigned to review and develop a systematic, integrated approach to internationalizing the campus. ${ }^{9}$ Trends in five areas of international education are discussed below and their implications for academic librarianship are identified.

\section{FOREIGN LANGUAGE INSTRUCTION}

Institutions are reconsidering the purpose, levels and outcomes of foreign language instruction. There is a new emphasis on requiring all students to attain a minimal-level proficiency in a second language. A second strategy concentrates on a narrower set of students who will attain a higher level of skill. This subset of students expands to nontraditional fields outside the liberal arts. The University of Rhode Island, for example, launched a pilot program in 1988 that combines a standard engineering curriculum with intensive study in German language and culture. It includes a six-month internship with an engineering company in a German-speaking country, and, upon return from abroad, an engineering course taught in German. ${ }^{10}$

In order to attract students to this type of program, colleges and universities are identifying motivated, high-aptitude learners in high school and targeting groups such as returned U.S. exchange students as potential participants. The HEP survey found that in the last five years, about 100 four-year colleges have increased their language requirements for admission, and that about 200 have increased them for a baccalaureate. ${ }^{11}$

Another trend in foreign language instruction is increasing enrollment in nonEuropean languages. One-third of the institutions in the HEP survey showed increases in the number of students enrolled in non-Western languages. ${ }^{12}$ Figures released by the Modern Language Association corroborate these findings. From 1983 to 1986, the number of college students enrolled in Japanese increased $45 \%$, to 23,454 . During the same period, 
the number of college students enrolled in Chinese increased by $28.2 \%$ and in Russian by $11.8 \%$. In contrast, French enrollments were up by only $1.9 \%$ and German declined by $5.6 \%$. $^{13}$

Finally, new measures are being developed to assess students' foreign language ability, with greater emphasis on actual performance and outcomes' assessment. Eventually, college curricula are likely to articulate more explicitly the levels of language offered, alongside the expected performance outcomes. Colleges and universities are working more closely with elementary and secondary schools to offer a continuum of foreign language training that extends from K-12 to college and beyond. ${ }^{14}$

\section{"As students become more conver- sant in foreign languages and the cur- riculum develops in languages other than English, new demands will be placed on libraries' human and mate- rial resources."}

The need for a highly trained, internationally astute cadre of academic librarians is evident. As students become more conversant in foreign languages and the curriculum develops in languages other than English, new demands will be placed on libraries' human and material resources. Higher-aptitude learners in foreignlanguage content courses will need foreign-language materials outside traditional, literary fields. Academic librarians can expect requests for business materials in Japanese, engineering in German, or journalism in Chinese. They must be prepared to identify and obtain these resources.

\section{STUDY ABROAD}

Traditionally, U.S. institutions of higher education have practiced a laissez-faire approach to study abroad. Although most four-year colleges and universities operate study-abroad programs (63 percent, according to the HEP survey), few have been developed as an integral part of the curriculum, and despite the number of programs available, relatively few students take advantage of them. ${ }^{15}$ There is a proliferation of programs, many overlapping in destination (largely European) and intent (largely general liberal arts), and often without quality control. Most institutions have not reviewed study abroad in terms of its relationship to the curriculum or the students' academic goals.

Current trends point first towards increasing the sheer number of college students who participate in study abroad. The European Economic Community (EEC) plans to send at least 10 percent of the students from each country to study in another member country as part of the EEC's 1992 integrated market concept. ${ }^{16}$ Similarly, an advisory panel to the Council on International Educational Exchange (CIEE) released a report in December 1988, Educating for Global Competence, that called for an increase in the number of Americans studying abroad to 10 percent of enrollment by 1995 and 20 to 25 percent by $2008 .^{17}$ The University of Minnesota has set a goal of reaching parity in the number of foreign students it receives and the number of U.S. students it sends abroad within the next ten years. This would mean a fourfold increase from the current 800 students, to 1,600 in 1993, and 3,200 in 1998; still less than 10 percent of the student population at the University of Minnesota.

In study abroad, there is also a movement to expand non-European opportunities and to relate study abroad to the academic curriculum, both before and after the term overseas. Most research on the impact of study abroad has concentrated on its character-building and cultural value, nearly excluding the evaluation of academic benefits and any gain in substantive knowledge. This is likely to change as institutions review systematically the purpose of study abroad and make it an integral part of the curriculum across all disciplines. ${ }^{18}$

As more students seek opportunities to study abroad, academic librarians can anticipate a demand for information about 
exchange programs. Moreover, students may want practical information about current social and economic conditions in the countries where they plan to study. If the library chooses not to acquire such practical guides itself, librarians should at least know which offices on their campus do offer services and advice on study abroad.

\section{INTERNATIONALIZING THE CURRICULUM}

To prepare students to live in a multicultural, interdependent world, institutions must pursue a strategy of infusing the general education curriculum with international content, while at the same time maintaining and improving concentrations and majors in international studies for a smaller subset of students. According to the HEP survey, just less than half ( 49 percent) of four-year colleges and universities reported an increase in the integration of international materials into regular courses. This seems to confirm the earlier findings reported in ACE's Campus Trends, 1986, which concluded that about two-fifths of the four-year institutions are increasing or have recently increased attention to international matters in their curriculum. ${ }^{19}$

\section{"As faculty develop the international content of their courses, they will rely more on international library re- sources and networks."}

As faculty develop the international content of their courses, they will rely more on international library resources and networks. National resource collections, along with the specialists capable of developing them, will become insufficient. Knowledge of -if not access tointernational sources will be required. In an international affairs course at the University of Maryland, students are linked via a computer network, created by the State Department, to European universities and strive to resolve geopolitical problems. Acting as diplomats for their respec- tive countries, students carry out all correspondence in target languages. ${ }^{20}$ This type of course is likely to place new demands on academic libraries.

\section{FOREIGN STUDENTS AND SCHOLARS}

Foreign student enrollments in U.S. institutions have increased tenfold in the last thirty-five years to a current figure of about 350,000 . While foreign students constitute less than 3 percent of all higher education enrollments in the United States, they now sustain academic programs on some campuses, particularly at graduate and professional levels. Since the mid-1980s, public attention has been drawn to enrollment and graduation figures in the technical fields where foreign students predominate. ${ }^{21}$ At the University of Minnesota, foreign students comprise about 20 percent of the total graduate student population; however, they represent over 50 percent in fields such as agricultural economics, agricultural engineering, animal science, civil engineering, economics, fluid mechanics, mathematics, mineral engineering, and veterinary medicine. On many campuses, foreign students are critical not only to the survival of graduate education in these fields, but also to the future labor force of U.S. corporations. ${ }^{22}$

Academic librarians need to evaluate the relevance of their collections and services to foreign students. They should know the demographic profile of foreign students on their campuses, the countries (and languages) they represent and their fields of study. Are foreign students provided with a frame of reference for using academic libraries effectively? Foreign students are also primary resources, on the campus and in the classroom, to internationalize the curriculum. But relevant library materials are needed to validate their interpretations. Do academic libraries have resources available in the vernacular to meet this need? Should librarians attempt to acquire materials relevant to foreign students' native countries so they might apply their knowledge effectively upon their return home? 


\section{TECHNICAL ASSISTANCE AND INTERNATIONAL DEVELOPMENT}

For several decades, public research universities, in particular, have been involved in projects with developing countries that concentrate on institutionbuilding, education and training, and technical assistance. Typically these projects have been funded by domestic and international agencies like the U.S. Agency for International Development, the World Bank, the World Health Organization, the Ford Foundation, and the Asian Development Bank. Such projects send U.S. faculty as visiting scholars overseas as well as bring foreign students and scholars to the United States.

The Midwest Universities Consortium for International Activities (MUCIA), composed of eight major public universities in the Midwest, manages large-scale international development projects that require combined scholarly resources. Since 1977, it has operated long-term programs in such countries as Indonesia, Thailand, Nepal, Burma, Korea, Bangladesh, Brazil, Peru, and the West Indies.

In January 1987, MUCIA signed a fiveyear, \$61 million subcontract with the World Bank to the Government of Indonesia (WBXVII). Based on the premise that Indonesia's social and economic growth are impeded by the lack of trained personnel, the project seeks to strengthen Indonesia's capacity to train its own university instructors and researchers. Specifically, MUCIA will provide: (a) graduate degree training for Indonesian students at overseas institutions (2,300 person-years); (b) internships and other nondegree training for Indonesian faculty and staff $(2,240$ person-months); and (c) technical research assistance by U.S. faculty sent to Indonesia as visiting scholars $(1,900$ person-months). The project is targeted to the fields of economics, life sciences, food science and nutrition, engineering, social studies, computer science, and biotechnology. ${ }^{23}$

Technical assistance projects vary from institution to institution, but academic librarians should be familiar with local priorities and commitments. Ideally, academic librarians would be involved during contract negotiations, since exchange of research materials is often an integral part of the proposal. Moreover, academic libraries might participate more fully in other aspects of these projects by sending their library staff overseas and agreeing to train librarians from abroad at their home institutions.

\section{SUMMARY}

Library professionals can no longer seek resolution to problems in parochial ways. The publishing industry itself has globalized: books written by authors in the United States are published by multinational corporations in the Netherlands, printed in Korea, priced differentially according to geographic markets, and distributed worldwide. To be effective, academic librarians must understand the new international marketplace. Even "local" problems such as preservation, database development, and cataloging standards must be considered in their international context.

The American Library Association (ALA) appears to have adopted an approach to international education similar to that of most institutions of higher education: random, decentralized, and ad hoc. The average ALA member needs a veritable road map through the thicket of ALA international library committees, and is hard put to understand whether and how these disparate committees cooperate to accomplish associational goals. $^{24}$

The Association of College and Research Libraries (ACRL) should work with ALA to focus and target its international efforts in order to avoid needless redundancies in some areas and glaring gaps in others. ACRL should reexamine the way in which it contributes to international education and strengthen its commitment for advocacy. It could provide leadership in the following areas:

1. Liaison with key national and international associations and programs that fund, promote, and evaluate international exchange in higher education such as the Association of International Education Administrators (AIEA) and the Coalition for the Advancement of Foreign Language and International Studies (CAFLIS). 
ACRL should appoint representatives to a broader network of these associations. It should take the lead in articulating the academic library dimensions of the numerous reports about international education cited in this paper and bringing them to the attention of the sponsoring agencies. With these agencies, ACRL should identify new sources of funding and lobby for resources to support the international dimensions of academic librarianship. (See appendix for list of relevant agencies.)

2 . Rather than serving as a clearinghouse for individual exchange placement requests from librarians abroad, ACRL might focus its attention first on encouraging such programs as IREX (International Research and Exchanges Board) and Fulbright to promote the exchange of librarians, following the successful prototype of the Library/Book Fellows program with USIA. ACRL could become the chief consultant in identifying appropriate institutions to meet the needs of exchange scholars and encouraging colleges and universities to host exchangees under the auspices of established international sponsors.

3. Within its field of responsibility, ACRL should promote quality control over international exchanges, tours, courses and other initiatives by offering critical reviews, writing guidelines, and identifying trained consultants during project development. CERL News might begin a regular international news column.

4. Through internationalization of its strategic plan, ACRL should ensure that its committees and sections integrate an international perspective into their work. It should support the work of its area studies sections, in particular, by ensuring their representation on appropriate ALA committees and using them as a network of consultants on various projects. All geographic areas, including Western and Eastern Europe, should be represented.

5. ACRL should recommend policies and mechanisms for academic libraries to compete for grants and gifts to support the international exchange of academic librarians and materials.

6. ACRL should develop guidelines and mechanisms for academic librarians to receive training and professional development opportunities in international areas. This effort should begin with library school training and extend throughout the career phases of academic librarianship.

\section{REFERENCES AND NOTES}

1. President's Commission on Foreign Language and International Studies, Strength through Wisdom: A Critique of U.S. Capability (Washington, D.C.: [Dept. of Health, Education, and Welfare, Office of Education], 1979).

2. Thomas S. Barrows and others, College Student's Knowledge and Beliefs: A Survey of Global Understanding (New Rochelle, N.Y.: Change Magazine Press, 1981).

3. See bibliography for list of recent studies in international education.

4. From CAFLIS "Working Group I" draft of January 31, 1989: "A Proposed Position for the Coalition for Advancement of Foreign Languages and Area Studies." This proposal builds on the earlier work of: Richard D. Lambert, Points of Leverage: An Agenda for a National Foundation for International Studies (New York: Social Science Research Council, 1986).

5. National Governors' Association, America in Transition: The International Frontier, Report of the Task Force on International Education (Washington, D.C.: NGA, 1989).

6. See: "The Global Imperative," The New York Times, 9 April 1989.

7. Charles J. Andersen, International Studies for Undergraduates, 1987: Operations and Opinions. Higher Education Panel Report Number 76, (Washington D.C.: American Council on Education, 1988).

8. Richard D. Lambert, International Studies and the Undergraduate (Washington, D.C.: American Council on Education, 1989), p.9-10. This is a summary of the full report that was to be released in spring of 1989.

9. See: Association of International Education Administrators, "Guidelines for International Education at U.S. Colleges and Universities," April 1989. Final draft distributed for approval by members on April 14, 1989. 
10. "Ideas: Teaching German to Engineers; . . .," Chronicle of Higher Education, 1 September 1988.

11. Andersen, p.8.

12. Ibid.

13. "Fascination with Business and the Orient Fuels Enrollment in Asian Languages," Chronicle of Higher Education, 17 February 1988.

14. Lambert, International Studies and the Undergraduate, p.5.

15. Anderson, p.4. and Lambert, p.1-5.

16. Lambert, p.1.

17. Council on International Educational Exchange, Educating for Global Competence: The Report of the Advisory Council for International Educational Exchange (New York: Council on International Educational Exchange, 1988), p.11.

18. Lambert, p.5.

19. Anderson, p.7-8 and Elaine El-Khawas, Campus Trends, 1986 (Washington, D.C.: American Council on Education, August 1986), p.3.

20. Torrey Byles, "Academic Computing Comes of Age," Wilson Library Bulletin, (Feb. 1989), p.23.

21. See, for example: The Wall Street Journal, 17 October 1985, p.29 and Change, July/August 1987.

22. "'Strengthening U.S. Engineering through International Cooperation," a Report of the Committee on International Cooperation in Engineering, National Academy of Engineering and Office of International Affairs, (Washington, D.C.: National Research Council, 1987).

23. Julie Nester-Niederman, "MUCIA: Midwest Universities Consortium for International Activities," Quarterly University International News, (Winter 1988), p.11-12 (publication of the University of Minnesota's Office of International Education).

24. See White Paper drafted by Robert P. Doyle, Director, Library/Book Fellows Program, "The American Library Association and International Relations: Accomplishments, Current Activities, Observations, Strategies, and Plan of Action" (Chicago: American Library Assn., November 1988).

\section{APPENDIX A: INTERNATIONAL EDUCATION: SELECTIVE BIBLIOGRAPHY OF NEWS, TRENDS, AND GUIDELINES}

\section{Recent News Articles on International Education}

"Colleges Must Improve Study-Abroad Programs or Risk Diminished American Stature, Panel Says," Chronicle of Higher Education, December 7, 1988, A32.

"Dearth of American Engineering Graduate Students Concerns Academicians," Black Issues in Higher Education, March 16, 1989, 1, 6-7.

"Fascination with Business and the Orient Fuels Enrollment in Asian Languages," Chronicle of Higher Education, February 17, 1988.

"The Global Imperative," The New York Times, April 9, 1989.

"Ideas: Teaching German to Engineers; . . . ," Chronicle of Higher Education, September 1, 1988.

"Portrait: A New President Gets Her Chance to Indulge Long-Time Passion for International Studies," Chronicle of Higher Education, March 22, 1989, A3.

Rentz, Mark D. "'My Turn: Diplomats in our Backyard," Newsweek, February 16, 1987, 10.

Simon, Paul. "Point of View: We Must Increase, Not Cut, Scholarly Exchanges," Chronicle of Higher Education, July 30, 1986, A60.

Trends in International Education

American Association of State Colleges and Universities. Trends and Issues in Globalizing Higher Education. Washington, D.C.: AASCU, 1977.

Anderson, Charles J. International Studies for Undergraduates, 1987: Operations and Opinions. Washington, D.C.: American Council on Education, September 1988. (Higher Education Panel Reports, Number 76).

Backman, Earl, ed. Approaches to International Education. New York: Macmillan, 1984,356p.

Barber, Elinor G., ed., et al. Bridges to Knowledge: Foreign Students in Comparative Perspective. Chicago: University of Chicago Press, 1984.

Barrows, Thomas, John Clark, and Stephen Klein. "What College Seniors Know About Their World," Education and the World View, New Rochelle, N.Y.: Change Magazine Press, 1980, p.19-37.

Barrows, Thomas and others. College Student's Knowledge and Beliefs: A Survey of Global Understanding, 
The Final Report of the Global Understanding Project, New Rochelle, N.Y.: Change Magazine Press, 1981.

Berryman, Sue E., Paul F. Langer, John Pincus, and Richard H. Solomon. Foreign Language and International Studies Specialists: The Marketplace and National Policy. Santa Monica, Calif.: Rand Corporation, 1979.

Boyles, Torrey. "Academic Computing Comes of Age," Wilson Library Bulletin, February 1989, p.21-28.

Burn, Barbara B. Expanding the International Dimension of Higher Education. San Francisco, Calif.: JosseyBass, 1980, $175 \mathrm{p}$.

Council on Learning. The Role of the Scholarly Disciplines. New Rochelle, N.Y.: Change Magazine Press, 1980,43 p.

Council on Learning. Education for a Global Century: Handbook of Exemplary International Programs. New Rochelle, N.Y.: Change Magazine Press, 1981, 157p.

Council on International Educational Exchange. Educating for Global Competence: The Report of the Advisory Council for International Educational Exchange. New York: Council on International Educational Exchange, August 1988.

Doyle, Robert P. "The American Library Association and International Relations: Accomplishments, Current Activities, Observations, Strategies, and Plan of Action," Chicago: ALA, November 1988. (Unpublished "White Paper.")

El-Khawas, Elaine. Campus Trends, 1986. Washington, D.C.: American Council on Education, 1986.

Groenings, Sven. Economic Competitiveness and International Knowledge, Staff Paper II. Boston: New England Board of Higher Education, October 1987.

Groenings, Sven. The Impact of Economic Globalization on Higher Education, Staff Paper III. Boston: New England Board of Higher Education, December 1987.

"Issues in International Education," NCA Quarterly, vol. 63, no. 2 (Fall 1988).

Lambert, Richard D. Beyond Growth: The Next Stage in Language and Area Studies. Washington, D.C.: Association of American Universities, 1984.

Lambert, Richard D. "Durable Academic Linkages Overseas: A National Agenda," in Annals of the American Academy of Political and Social Science, vol. 491, (May 1987), p.140-55.

Lambert, Richard D. International Studies and the Undergraduate. Washington, D.C.: American Council on Education, 1989, 10 p.

Lambert, Richard, D. ed. "New Directions in International Education," Annals of the American Academy of Political and Social Science, vol. 449, (May 1980), 224p.

Lambert, Richard D. Points of Leverage: An Agenda for a National Foundation for International Studies. New York: Social Science Research Council, 1986.

Leinwand, Gerald. Without a Nickel: The Challenge of Internationalizing the Curriculum and the Campus. Washington, D.C.: American Association of State Colleges and Universities, 1983, 55p.

McDonnell, Lorraine M., Sue E. Berryman, and Douglas Scott. Federal Support for International Studies: The Role of NDEA Title VI. Santa Monica, Calif.: Rand Corporation, 1981.

National Governors' Association. America in Transition: The International Frontier. Report of the Task Force on International Education. Washington, D.C.: NGA, 1989.

President's Commission on Foreign Language and International Studies. Strength through Wisdom: A Critique of U.S. Capability. Washington, D.C.: U.S. Dept. of Health, Education, and Welfare, Office of Education, 1979.

Rosengran R., M. Wiley, and D. Wiley. Internationalizing Your School: A Handbook and Resource Guide for Teachers, Administrators, Parents, and School Board Members. New York: National Council on Foreign Language and International Studies, 1983, 63p.

Simon, Paul. The Tongue-Tied American: Confronting the Foreign Language Crisis. New York: Continuum, 1980, 214p.

Smuckler, Ralph H., Robert J. Berg, with David F. Gordon. New Challenges, New Opportunities: U.S. Cooperation for International Growth and Development in the 1990s. East Lansing: Michigan State University, Center for Advanced Study of International Development, 1988, 40p.

"Strengthening U.S. Engineering Through International Cooperation," A Report of the Committee on International Cooperation in Engineering, National Academy of Engineering and Office of International Affairs, Washington, D.C.: National Research Council, 1987.

Tonkin, H. and Jane Edwards. The World in the Curriculum: Curricular Strategies for the 21st Century. New Rochelle, N.Y.: Change Magazine Press, 1981.

Guidelines for International Education

American Association of State Colleges and Universities. Guidelines: Incorporating an International Di- 
mension in Colleges and Universities. Washington, D.C.: AASCU.

American Council on Education, Division of International Education. Guidelines for College and University Linkages Abroad. Washington, D.C.: American Council on Education, 1984.

Association of International Education Administrators. Guidelines for International Education at U.S. Colleges and Universities. Final Draft, April 1989.

College Entrance Examination Board. Guidelines for the Recruitment of Foreign Students. New York: College Entrance Examination Board, 1987.

Harari, Maurice. Internationalizing the Curriculum and the Campus: Guidelines for AASCU Institutions. Washington, D.C.: American Association of State Colleges and Universities, 1983.

King, Maxwell, and Seymour Fersh. International Education and the U.S. Community College: From Optional to Integral. Junior College Resource Review, Spring 1983. Washington, D.C.: National Institute of Education, 1983.

Middle States Association of Colleges and Schools. Commission on Higher Education. Manual for Study Abroad Evaluations., August 1987.

Miller, Harry G. and E. Hollis Merritt. "Technical Assistance Projects in Developing Countries: The Role of Public Universities," Journal of Studies in Technical Careers, vol. 7, no. 2 (Spring 1985): 73-80.

National Association for Foreign Student Affairs. NAFSA Principles for International Educational Exchange. Washington, D.C.: NAFSA, 1983, 16p.

National Association for Foreign Student Affairs. NAFSA Self-Study Guide: A Guide for the SelfAssessment of Programs and Services with International Educational Exchange at Postsecondary Institutions. Washington, D.C.: National Association for Foreign Student Affairs, 1984.

National Association for Foreign Student Affairs. Self-regulation Bibliography. Washington, D.C.: National Association for Foreign Student Affairs, 1986.

National Association for Foreign Student Affairs. Study Abroad Programs: An Evaluation Guide. Washington, D.C.: National Association for Foreign Student Affairs, 1979.

National Association of State Universities and Land-Grant Colleges. International Affairs Committee. Basic Principles for College and University Involvement in International Development Activities. Washington, D.C.: National Association of State Universities and Land-Grant Colleges, 1983.

Rhinesmith, Stephen H. "Negotiating International Youth Exchange Agreements," International Youth Exchange Conference, Williamsburg, Virginia, January 25, 1983. See also "Workshop Reports," same conference.

\section{APPENDIX B: U.S. AGENCIES AND ASSOCIATIONS IN INTERNATIONAL EDUCATIONAL EXCHANGE}

\section{Higher Education Agencies with International Dimension}

Academy for Educational Development

American Assembly of Collegiate Schools of Business

American Association for the Advancement of Science-Consortium of Affiliates for International Programs

American Association of Collegiate Registrars and Admissions Officers

American Association of Community and Junior Colleges

American Association of State Colleges and Universities

American Association of University Women

American Council of Learned Societies

American Council on Education

Andrew Mellon Foundation

Association of Catholic Colleges and Universities

Association of Jesuit Colleges and Universities

Carnegie Corporation

College Board, Office of International Education

College Entrance Examination Board

Committee on Institutional Cooperation

Council of Graduate Schools

Council on Learning

Dumbarton Oaks 
Educational Testing Service, International Office

Ford Foundation

Higher Education Consortium for Urban Affairs

Luce Foundation

MacArthur Foundation

National Academy of Sciences

National Association of State Universities and Land-Grant Colleges

National Science Foundation

Olin Foundation

Pew Charitable Trust

Rockefeller Foundation

Sloan Foundation

Smithsonian Institution

Social Science Research Council

Spenser Foundation

U.S. Department of Education (Fulbright-Hays programs and Title VI centers)

William \& Flora Hewlett Foundation

\section{International Agencies}

Academic Alliances in Foreign Languages and Literatures

American Field Service

Association for International Practical Training

Association for Women in Development

Association of International Education Administrators

Association of U.S. University Directors of International Agricultural Programs

Board for International Food and Agricultural Development

Coalition for Advancement of Foreign Languages and International Studies

Community Colleges for International Development, Inc.

Consortium for International Cooperation in Higher Education

Consortium for International Development

Consortium for International Studies Education

Council of International Exchange of Scholars

Council of International Programs

Council of International Programs for Youth Leaders and Social Workers, Inc.

Council on Foreign Relations

Council on International Educational Exchange

East-West Center

Fogarty International Center

Fulbright Alumni Association

HEA Title VI National Resource Centers for International Studies, Advanced Training and Research

Branch

Institute of International Education

International Association of Educators for World Peace

International Association of Universities

International Student Exchange Program

International Studies Association

Latin American Scholarship Program of American Universities

Liaison Group for International Educational Exchange

Mid-America International Agricultural Consortium (MIAC), Inc.

Midwest Universities Consortium for International Activities

National Association for Foreign Student Affairs

National Council for International Visitors

National Council of State Supervisors of Foreign Languages

National Council on Foreign Languages and International Studies

Post Secondary International Network

Rotary International

Society for Intercultural Education, Training and Research

South-East Consortium for International Development

University Affiliation Programs (USIA) 
Area Studies or Country-Specific Agencies

African American Institute

African Studies Association

Alexander von Humboldt-Stiftung

AMIDEAST

American Association for Netherlandic Studies

American Association of Teachers of German

American-Mideast Educational and Training Services, Inc.

American Oriental Society

American-Scandinavian Foundation Exchange Division

Association for the Advancement of Slavic Studies

Association for Asian Studies

Atlantic Exchange Program

Belgian American Educational Foundation

Center for Arabic Study Abroad

Commission of European Communities

Committee on Scholarly Communication with the People's Republic of China

Conference Group on German Politics

Council for European Studies

Council of American Overseas Research Centers (CAORC)

American Academy in Rome

American Institute for Yemeni Studies

American Institute of Indian Studies

American Institute of Iranian Studies

American Institute for Maghrib Studies

American Institute of Pakistan Studies

American Research Center in Egypt

American Research Institute in Turkey

American School of Classical Studies at Athens

American School of Oriental Research

German Marshall Fund

German Studies Association

Hariri Foundation

Institute for European Studies

Intercollegiate Center for Classical Studies in Rome

International Research and Exchanges Board (Soviet \& East European)

Japan Society for the Promotion of Science

Latin American Scholarship Program of American Universities

Latin American Studies Association

Middle East Studies Association

National Council for Soviet and East European Research

Society for the Advancement of Scandinavian Study

Society for French Historical Studies 